\title{
Cost and health consequences of reducing the population intake of salt
} Randi M Selmer, Ivar Sønbø Kristiansen, Anton Haglerød, Sidsel Graff-Iversen,
Hanne K Larsen, Haakon E Meyer, Kaare H Bønaa, Dag S Thelle
National Health

Screening Service, PO

Box 8155 Dep, N-0033

Oslo, Norway

R M Selmer

S Graff-Iversen

H E Meyer

Institute of Public

Health, Health

Economics Section,

University of Southern

Denmark, Odense,

Denmark

I S Kristiansen

Norwegian Institute of Agricultural

Economics, Oslo,

Norway

A Haglerød

National Council on

Nutrition and Physical

Activity, Oslo, Norway

H K Larsen

Institute of

Community Medicine,

University of Tromsø,

Tromsø, Norway

K H Bønaa

Sahlgrenska University Hospital/Östra, Göteborg, Sweden D S Thelle

Correspondence to: Dr Selmer

(rmselmer@online.no)

Accepted for publication 8 May 2000

\begin{abstract}
Study objective-The aim was to estimate health and economic consequences of interventions aimed at reducing the daily intake of salt (sodium chloride) by $6 \mathrm{~g}$ per person in the Norwegian population. Health promotion (information campaigns), development of new industry food recipes, declaration of salt content in food and taxes on salty food/subsidies of products with less salt, were possible interventions.

Design-The study was a simulation model based on present age and sex specific mortality in Norway and estimated impact of blood pressure reductions on the risks of myocardial infarction and stroke as observed in Norwegian follow up studies. A reduction of $2 \mathrm{~mm} \mathrm{Hg}$ systolic blood pressure (range 1-4) was assumed through the actual interventions. The cost of the interventions in themselves, welfare losses from taxation of salty food/subsidising of food products with little salt, cost of avoided myocardial infarction and stroke treatment, cost of avoided antihypertensive treatment, hospital costs in additional life years and productivity gains from reduced morbidity and mortality were included.
\end{abstract}

Results-The estimated increase in life expectancy was 1.8 months in men and 1.4 in women. The net discounted $(5 \%)$ cost of the interventions was minus $\$ 118$ millions (that is, cost saving) in the base case. Sensitivity analyses indicate that the interventions would be cost saving unless the systolic blood pressure reduction were less than $2 \mathrm{~mm} \mathrm{Hg}$, productivity gains were disregarded or the welfare losses from price interventions were high.

Conclusion-Population interventions to reduce the intake of salt are likely to improve the population's health and save costs to society.

(F Epidemiol Community Health 2000;54:697-702)

High consumption of dietary salt (sodium chloride) is positively associated with systolic and diastolic blood pressure. ${ }^{1}$ Arterial hypertension, in turn, increases the risk of cardiovascular disease, especially cerebral stroke and myocardial infarction.

Randomised trials of salt reductions targeted at people (normotensive or hypertensive) indicate that salt reductions reduce blood pressure, especially in the hypertensive. ${ }^{23}$ However, in studies where populations are randomised to intervention or non-intervention, the results are ambiguous. ${ }^{4-8}$ It is worthwhile noting, however, that the variation in blood pressure and sodium intake makes the interpretation of the studies difficult. In particular, the intraindividual day to day variation in sodium intake is greater than interindividual variation in mean sodium intake. It may well be that the effect of salt depletion on the blood pressure level also depends upon other dietary factors such as calcium, magnesium and potassium. ${ }^{9}$ This may be another explanation for the discrepant results between individual trials and population interventions. Despite these uncertainties, it seems reasonable to assume that reduced intake of salt will reduce the population blood pressure - that is, move the distribution to the left-and thereby reduce the risk of cardiovascular disease.

The aim of this study was to estimate health and economic consequences of interventions to reduce the intake of salt as suggested by the National Council on Nutrition and Physical Activity, Norway: information campaigns targeted at the whole population or special groups (for example, school children), developing industry food with less salt (new recipes), declaration of salt content for processed food and taxation/subsidising of processed food with high/little content of salt (bread, butter, cheese, pizzas, sausages, powder soups, etc). The National Council on Nutrition and Physical Activity has estimated that these interventions could half the intake of sodium from about $11 \mathrm{~g}$ per day. ${ }^{10}$ This corresponds to a decrease in sodium excretion of $100 \mathrm{mmol} /$ day, which was associated with a difference of $3-6 \mathrm{~mm} \mathrm{Hg}$ systolic blood pressure in the INTERSALT study $^{1}$ and a decrease of $2.2 \mathrm{~mm} \mathrm{Hg}$ in normotensive and a much larger decrease in hypertensive participants in individual intervention studies. ${ }^{2}{ }^{3}$ As a conservative estimate, we chose $2 \mathrm{~mm} \mathrm{Hg}$ systolic blood pressure in the base case analysis, while 1 and $4 \mathrm{~mm} \mathrm{Hg}$ were explored in sensitivity analyses.

A standard cost effectiveness approach was adopted with life years as the measure of health benefit. ${ }^{112}$ No intervention was used as comparator in the model.

\section{Methods}

THE MODEL

We developed a dynamic simulation model with alive and dead as the two principal health states. ${ }^{13}$ The population, aged 40 and older, was exposed to age and sex specific yearly risks of myocardial infarction (MI) and cerebral stroke, both fatal and non-fatal, and mortality 
Table 1 Parameters of the Markov model

\begin{tabular}{|c|c|c|c|c|}
\hline & Base case assumptions & Alternative assumptions & Source & Reference \\
\hline \multicolumn{5}{|l|}{ Health parameters } \\
\hline Mortality from MI and from stroke (current rates) & Age/sex specific rates Norway & Low: $25 \%$ lower & Statistics Norway & 14 \\
\hline Ratio of non-fatal to fatal MIs & $2: 1$ & $\begin{array}{l}\text { Low: } 1: 1 \\
\text { High: } 3: 1\end{array}$ & Finnmark Study & 15 \\
\hline Ratio of non-fatal to fatal strokes & $3: 1$ & $\begin{array}{l}\text { Low: } 2: 1 \\
\text { High: } 4: 1\end{array}$ & Innherred Study & 16 \\
\hline Reversibility of the risk of MIs & $100 \%$ & $50 \%$ & Bergen Study & 17 \\
\hline Reversibility of the risk of cerebral strokes & $100 \%$ & $50 \%$ & Bergen Study & 17 \\
\hline Reduction in systolic blood pressure & $2 \mathrm{~mm} \mathrm{Hg}$ & $\begin{array}{l}\text { Low: } 1 \mathrm{~mm} \mathrm{Hg} \\
\text { High: } 4 \mathrm{~mm} \mathrm{Hg}\end{array}$ & & 123 \\
\hline \multicolumn{5}{|l|}{ Economic parameters } \\
\hline $\begin{array}{l}\text { Cost of information campaigns and development of new } \\
\text { products with less salt (new recipes) }\end{array}$ & $\$ 2.9 \mathrm{mill} /$ year & $\begin{array}{l}\text { Low: } \$ 1.4 \text { mill } \\
\text { High: } \$ 5.7 \text { mill }\end{array}$ & Expert judgement & 10 \\
\hline Welfare losses from taxation/subsidising & $\$ 14$ mill/year & $\begin{array}{l}\text { Low: } \$ 0 \text { mill/year } \\
\text { Middle: } \$ 23 \text { mill/year } \\
\text { High: } \$ 143 \text { mill/year }\end{array}$ & Expert judgement & 10 \\
\hline Cost savings from reduced antihypertensive treatment & $\begin{array}{l}\$ 6 \text { mill per } 2 \mathrm{~mm} \mathrm{Hg} \text { reduction } \\
\text { in systolic blood pressure }\end{array}$ & $\begin{array}{l}\text { Low: } 0 \\
\text { High: } \$ 9 \text { mill per } 2 \mathrm{~mm} \text { reduction }\end{array}$ & Tromsø Study & 1819 \\
\hline Cost of in hospital care for MI & $\$ 7143$ & $\begin{array}{l}\text { Low: } \$ 3571 \\
\text { High: } \$ 10714\end{array}$ & DRG price list & 20 \\
\hline Cost of care for non-fatal stroke (one year cost) & $\$ 14286$ & $\begin{array}{l}\text { Low: } \$ 7143 \\
\text { High: } \$ 21429\end{array}$ & $\begin{array}{l}\text { DRG price list and } \\
\text { public accounts }\end{array}$ & 20 \\
\hline Cost of care for fatal stroke & $\$ 7857$ & $\begin{array}{l}\text { Low: } \$ 4643 \\
\text { High: } \$ 11071\end{array}$ & DRG price list & 20 \\
\hline Cost of in hospital care during extended life & $\begin{array}{l}\text { Age/sex specific DRG } \\
\text { utilisation rates }\end{array}$ & $\begin{array}{l}\text { Low: } 50 \% \\
\text { High: } 200 \%\end{array}$ & $\begin{array}{l}\text { National DRG } \\
\text { statistics }\end{array}$ & 20 \\
\hline Mean annual income incl. employer tax & $\$ 31429$ & $\begin{array}{l}\text { Low: } \$ 25714 \\
\text { High: } \$ 37143\end{array}$ & Statistics Norway & 23 \\
\hline Proportion non-retired & Age/sex specific rates & $\begin{array}{l}\text { Low: } 10 \% \text { lower } \\
\text { High: } 10 \% \text { higher }\end{array}$ & Statistics Norway & 23 \\
\hline Elasticity factor & 0.8 & $\begin{array}{l}0.0 \\
1.0\end{array}$ & & 24 \\
\hline Discount rate & $5 \%$ & $\begin{array}{l}0 \% \\
3.5 \% \\
7 \% \\
10 \%\end{array}$ & & 25 \\
\hline
\end{tabular}

from all other causes. New generations enter the model as they reach the age of 40 . The baseline population was the Norwegian population as of 1 January 1995 . We assumed interventions over 25 years and that the effects appear gradually over five years from the onset of intervention. Potential life years saved after 25 years of interventions were estimated applying pre-intervention mortality rates.

An overview of the model parameters with baseline and alternative assumptions is shown in table 1 .

HEALTH PARAMETERS

Reductions of MI and stroke mortality were modelled as a function of systolic blood pressure (see below) while mortality from other causes was kept constant at current levels. ${ }^{14}$

The risk of fatal MI and stroke was taken from mortality statistics. ${ }^{14}$ We assumed, according to the Finnmark Study, that two non-fatal cases of MI occurred for each fatal case, ${ }^{15}$ and according to the Innherred Study three non-fatal cases of stroke occurring for each fatal one. ${ }^{16}$

In the base case we assumed full reversibility of the risk as calculated from the blood pressure-mortality associations in the Bergen Study. ${ }^{17}$ The regression coefficients were adjusted upwards by a factor of 1.4 in women and 1.5 in men to take account of regression dilution bias.

ECONOMIC PARAMETERS

All costs were measured in $1997 \mathrm{Kr}(\$ 1=\mathrm{Kr} 7)$. The cost of information campaigns and development of new industry food products with less salt ( $\$ 2.9$ millions per year through seven years, later $\$ 1.4$ millions per year) were based on expert opinions. ${ }^{10}$ The welfare losses ( $\$ 14$ million/y) from taxes on salty food/subsidies on food products with little salt, were estimated on the basis of the annual weight of purchased salty food, the cost per kilo of such food and on the price elasticity of supply and demand of such products.

The annual cost of antihypertensive drugs is about $\$ 86$ millions in Norway for 250000 patients. ${ }^{18}$ Additionally, about $\$ 43$ millions are spent on physician consultations. Cost reductions from less antihypertensive treatment were estimated assuming that costs decrease proportional to the number of patients. Expected reductions in the number of patients on treatment were estimated from a logistic model for the associations between the odds of being treated and blood pressure in the Tromsø Study. ${ }^{19}$

Cost savings from avoided events were based on the predicted number of events and their unit costs. Hospital costs were based on DRG data $^{20}$ (table 1). We used an average of $\$ 7143$ per avoided case of MI which is in line with a Swedish cost study ${ }^{21}$ and for stroke an average

Table 2 Mean cost (US \$) of hospital care for all conditions excluding cerebral stroke and myocardial infarction, per person per year by age and sex. Norway 1996

\begin{tabular}{lll}
\hline Age & Men & Women \\
\hline $40-49$ & 297 & 350 \\
$50-59$ & 573 & 527 \\
$60-69$ & 1044 & 781 \\
$70-79$ & 1626 & 1242 \\
$80-89$ & 1982 & 1585 \\
$90+$ & 1990 & 1655 \\
\hline
\end{tabular}

Source: Ministry of Health and Social Affairs, Oslo, Norway. 
Table 3 Expected reductions in annual mortality rates from cerebral stroke and myocardial infarction when the whole blood pressure distribution is moved towards lower values

\begin{tabular}{|c|c|c|c|c|c|c|c|c|}
\hline & \multicolumn{4}{|c|}{ Cerebral stroke } & \multicolumn{4}{|c|}{ Myocardial infarction } \\
\hline & \multirow{2}{*}{$\begin{array}{l}\text { Number of } \\
\text { deaths } \\
\text { Norway } \\
1994\end{array}$} & \multicolumn{3}{|c|}{$\begin{array}{l}\text { Per cent mortality reduction by a reduction } \\
\text { in systolic blood pressure of: }\end{array}$} & \multirow{2}{*}{$\begin{array}{l}\text { Number of } \\
\text { deaths } \\
\text { Norway } \\
1994\end{array}$} & \multicolumn{3}{|c|}{$\begin{array}{l}\text { Per cent mortality reduction by a reduction } \\
\text { in systolic blood pressure of: }\end{array}$} \\
\hline & & $1 \mathrm{~mm} \mathrm{Hg}$ & $2 \mathrm{~mm} \mathrm{Hg}$ & $4 \mathrm{~mm} \mathrm{Hg}$ & & $1 \mathrm{~mm} \mathrm{Hg}$ & $2 \mathrm{~mm} \mathrm{Hg}$ & $4 \mathrm{~mm} \mathrm{Hg}$ \\
\hline \multicolumn{9}{|c|}{ Age 40-69 } \\
\hline Men & 285 & 4.2 & 8.2 & 15.7 & 1493 & 2.6 & 5.1 & 9.9 \\
\hline $\begin{array}{l}\text { Women } \\
\text { Age } 70+\end{array}$ & 204 & 4.5 & 8.2 & 15.7 & 418 & 3.8 & 6.9 & 13.3 \\
\hline Men & 1762 & 2.2 & 4.4 & 8.5 & 3716 & 1.7 & 3.4 & 6.7 \\
\hline $\begin{array}{l}\text { Women } \\
\text { Age } 40+\end{array}$ & 2812 & 1.9 & 3.5 & 6.8 & 3396 & 1.7 & 3.2 & 6.3 \\
\hline Men & 2047 & 2.5 & 4.9 & 9.5 & 5209 & 2.0 & 3.9 & 7.6 \\
\hline Women & 3016 & 2.0 & 3.8 & 7.4 & 3814 & 2.0 & 3.6 & 7.1 \\
\hline Total & 5063 & 2.2 & 4.2 & 8.2 & 9023 & 2.0 & 3.8 & 7.4 \\
\hline
\end{tabular}

of $\$ 7857 .{ }^{20}$ Avoiding strokes also means avoiding lengthy stays in nursing home for some of the patients. One year stay in nursing home may cost in the order of $\$ 42857 .^{22}$ Lacking information on the proportion of patients admitted to nursing homes and their average length of stay, we assumed that the cost savings from one avoided non-fatal stroke would be $\$ 14286$ (no savings in subsequent years).

Cost of hospital care in additional life years was included in the total programme costs (table 2), but we detracted costs of hospitalisation for MI and stroke because they were already accounted for.

Productivity gains from reduced mortality were estimated on the basis of age and sex specific retirement rates and average annual income in Norway including payroll tax. ${ }^{23}$ The productivity gains were adjusted downwards by $20 \%$ according to the friction costs method (elasticity factor $=0.8) .{ }^{24}$ Time costs avoided because fewer patients are on antihypertensive treatment were estimated from national hourly wage rates. Future costs and health benefits were discounted by $5 \%$ in the base case while $0 \%, 3.5 \%, 7 \%$ and $10 \%$ were used in sensitivity analyses. ${ }^{25}$

Table 4 Predicted health consequences over 25 years, of $2 \mathrm{~mm} \mathrm{Hg}$ reduction in systolic blood pressure in the whole population in Norway. Discount rate 0.05

\begin{tabular}{|c|c|c|c|c|c|c|}
\hline \multirow[b]{2}{*}{ Year } & \multicolumn{2}{|c|}{$\begin{array}{l}\text { Reduction in number of } \\
\text { fatal events from }\end{array}$} & \multicolumn{2}{|c|}{$\begin{array}{l}\text { Reduction in number of } \\
\text { non-fatal events from }\end{array}$} & \multirow{2}{*}{$\begin{array}{l}\text { Life years } \\
\text { saved }\end{array}$} & \multirow{2}{*}{$\begin{array}{l}\text { Discounted } \\
\text { life years } \\
\text { saved }\end{array}$} \\
\hline & $M I^{\star}$ & stroket & $M I$ & stroke & & \\
\hline $1-5$ & 1014 & 646 & 2029 & 1939 & 2674 & 2195 \\
\hline $6-10$ & 1615 & 1036 & 3231 & 3109 & 12101 & 8087 \\
\hline $11-15$ & 1535 & 960 & 3070 & 2881 & 19714 & 10417 \\
\hline $16-20$ & 1517 & 905 & 3034 & 2716 & 24642 & 10231 \\
\hline $21-25$ & 1600 & 925 & 3200 & 2774 & 28225 & 9190 \\
\hline $1-25$ & 7281 & 4472 & 14564 & 13419 & 87356 & 40120 \\
\hline $25+$ & -1137 & -786 & -2273 & -2358 & 61163 & 12173 \\
\hline Total & 6144 & 3686 & 12291 & 11061 & 148519 & 52293 \\
\hline
\end{tabular}

^MI: myocardial infarction; †stroke: cerebral stroke.

Table 5 Expected reductions in percentage of population receiving antihypertensive treatment by 1, 2 and $4 \mathrm{~mm} \mathrm{Hg}$ reduction of systolic blood pressure (SBP)

\begin{tabular}{|c|c|c|c|c|c|c|}
\hline \multirow[b]{3}{*}{ Population } & \multicolumn{3}{|c|}{ The Tromsø Study } & & & \\
\hline & \multirow[b]{2}{*}{ Number } & \multicolumn{2}{|c|}{$\begin{array}{l}\text { Receiving } \\
\text { antihypertensive treatment }\end{array}$} & \multicolumn{3}{|c|}{$\begin{array}{l}\text { Expected per cent reduction in number } \\
\text { treated by a reduction in SBP of }\end{array}$} \\
\hline & & $n$ & Per cent & $1 \mathrm{~mm} \mathrm{Hg}$ & $2 \mathrm{~mm} \mathrm{Hg}$ & $4 \mathrm{~mm} \mathrm{Hg}$ \\
\hline No heart disease & 24338 & 935 & 3.8 & 3.0 & 5.9 & 11.4 \\
\hline With heart disease & 1939 & 623 & 32.1 & 1.8 & 3.5 & 6.9 \\
\hline Total & 26277 & 1558 & 5.9 & 2.5 & 4.9 & 9.6 \\
\hline
\end{tabular}

Based on the probable range of each parameter, one and two way sensitivity analyses were undertaken.

\section{Results}

REDUCTIONS IN THE RISK OF STROKE AND MI

The overall expected risk reduction was 4.2 per cent for stroke and 3.8 per cent for MI when systolic blood pressure is reduced by $2 \mathrm{~mm} \mathrm{Hg}$ (table 3).

The reduction in mortality from stroke and MI implies $1-2 \%$ reductions in the total mortality rates. This means an increase in life expectancy by 1.8 months and 1.4 months in 40 year old men and women.

HEALTH CONSEQUENCES OF 25 YEARS OF BLOOD PRESSURE REDUCTIONS

During the 25 year period, the estimated reductions in fatal events were 7000 for $\mathrm{MI}$ and 4500 for stroke (table 4). The estimated number of life years saved was 87000 over the 25 years and 6000 more people would be alive at the end of the period. The average number of potential life years saved for these survivors is 10 life years after the 25 years programme period, resulting in totally 150000 life years saved (table 4) or 52000 when discounted at $5 \%$ rate.

NUMBER OF PEOPLE RECEIVING

ANTIHYPERTENSIVE TREATMENT

In the Tromsø Study 5.9 per cent were receiving antihypertensive treatment (table 5). The percentage receiving treatment increased with increasing blood pressure. From logistic regression models, adjusted for age, sex and body mass index, it was estimated that the number using antihypertensive drugs would be reduced by $4.9 \%$ if systolic blood pressure were reduced by $2 \mathrm{~mm} \mathrm{Hg}$.

\section{ECONOMIC CONSEQUENCES}

The estimated net savings of the programme over 25 years were $\$ 270$ millions, or $\$ 120$ millions when discounted at $5 \%$ (table 6 ). The net economic consequences over the whole period until all persons are deceased, are cost savings in the order of $\$ 240$ millions ( $\$ 120$ millions when discounted). 
Table 6 Economic consequences (million US \$) of 25 years of interventions to reduce the intake of salt (base case assumptions)

\begin{tabular}{|c|c|c|c|c|c|c|c|c|c|c|c|}
\hline \multirow[b]{2}{*}{ Year } & \multicolumn{5}{|l|}{ Avoided costs } & \multicolumn{4}{|l|}{ Costs } & \multicolumn{2}{|l|}{ Net costs } \\
\hline & $\begin{array}{l}\text { Avoided care } \\
\text { for MI and } \\
\text { stroke }\end{array}$ & $\begin{array}{l}\text { Increased } \\
\text { productivity }\end{array}$ & $\begin{array}{l}\text { Reduced } \\
\text { antihypertensive } \\
\text { treatment }\end{array}$ & $\begin{array}{l}\text { Avoided } \\
\text { time losses }\end{array}$ & Total & $\begin{array}{l}\text { Cost of } \\
\text { health care } \\
\text { in extended } \\
\text { life }\end{array}$ & $\begin{array}{l}\text { Information } \\
\text { campaigns, } \\
\text { development } \\
\text { of new } \\
\text { recipes }\end{array}$ & $\begin{array}{l}\text { Welfare } \\
\text { losses from } \\
\text { taxation/ } \\
\text { subsidies }\end{array}$ & Total & Undiscounted & $\begin{array}{l}\text { Discounted } \\
(5 \%)\end{array}$ \\
\hline $1-5$ & 49 & 9 & 19 & 3 & 80 & 4 & 14 & 71 & 90 & 9 & 10 \\
\hline $6-10$ & 79 & 39 & 32 & 5 & 155 & 18 & 10 & 71 & 99 & -56 & -37 \\
\hline $11-15$ & 73 & 64 & 32 & 5 & 175 & 29 & 7 & 71 & 107 & -67 & -36 \\
\hline $16-20$ & 70 & 82 & 32 & 5 & 190 & 36 & 7 & 71 & 114 & -76 & -31 \\
\hline $21-25$ & 73 & 91 & 32 & 5 & 201 & 41 & 7 & 71 & 120 & -81 & -26 \\
\hline $1-25$ & 344 & 285 & 147 & 23 & 801 & 128 & 45 & 355 & 530 & -271 & -120 \\
\hline $25+$ & -58 & 119 & 0 & 0 & 61 & 95 & 0 & 0 & 95 & 34 & 3 \\
\hline Total & 286 & 404 & 147 & 23 & 862 & 223 & 45 & 355 & 625 & -237 & -117 \\
\hline
\end{tabular}

Table 7 Two way sensitivity analysis: cost per life year saved (US \$). Alternative assumptions

\begin{tabular}{|c|c|c|c|c|}
\hline \multicolumn{5}{|c|}{ Welfare losses $=\$ 14$ million } \\
\hline \multirow{2}{*}{$\begin{array}{l}\text { SBP reduction } \\
(\mathrm{mm} \mathrm{Hg})\end{array}$} & \multicolumn{4}{|c|}{ Elasticity factor } \\
\hline & $0^{*}$ & 0.8 & 1 & \\
\hline 1 & 5313 & 2040 & 1222 & \\
\hline 2 & 1002 & Cost saving $†$ & Cost saving & \\
\hline 4 & Cost saving & Cost saving & Cost saving & \\
\hline \multicolumn{5}{|c|}{ Elasticity factor $=0.8$} \\
\hline \multirow{2}{*}{$\begin{array}{l}\text { SBP reduction } \\
(\mathrm{mm} \mathrm{Hg})\end{array}$} & \multicolumn{4}{|c|}{ Welfare losses (million \$) } \\
\hline & 0 & 14 & 23 & 143 \\
\hline 1 & Cost saving & 2040 & 6606 & 70534 \\
\hline 2 & Cost saving & Cost saving† & 55 & 32398 \\
\hline 4 & Cost saving & Cost saving & Cost saving & 13326 \\
\hline
\end{tabular}

$S B P$ reduction $=2 \mathrm{~mm} \mathrm{Hg}$

Welfare losses (million \$)

\begin{tabular}{lllll}
\cline { 2 - 5 } Elasticity factor & 0 & 14 & \multicolumn{1}{l}{23} & 143 \\
\hline 0 & Cost saving & 1002 & 3312 & 35655 \\
0.8 & Cost saving & Cost saving & 55 & 32398 \\
1 & Cost saving & Cost saving & Cost saving & 31584 \\
\hline \multirow{2}{*}{ Productivity gains disregarded. †Base case assumptions. } & &
\end{tabular}

\section{SENSITIVITY ANALYSIS}

Changing one parameter at a time, there were net cost savings unless the blood pressure reduction was only $1 \mathrm{~mm} \mathrm{Hg}$, if welfare losses were high, or if productivity gains were disregarded (elasticity factor $=0$ ). The results were more sensitive to the size of blood pressure reduction at higher levels of welfare losses (table 7).

\section{Discussion}

The results of this analysis indicate that population reductions in the intake of salt will increase life expectancy and at the same time save costs to individuals and society. However, this conclusion is susceptible to changes in the assumptions upon which it was based.

The effectiveness of population programmes in reducing blood pressure is not fully established. If decisions are to be made now rather than in the future, we consider a $2 \mathrm{~mm} \mathrm{Hg}$ reduction to be a probable, but possibly conservative, estimate of the programme effectiveness.

The association between blood pressure and MI and stroke is well established. ${ }^{17}{ }^{26}{ }^{27}$ Pharmaceutical interventions have demonstrated risk reductions for stroke as one would expect from observational studies. ${ }^{28}$ For MI, the risk reductions have been smaller than expected. ${ }^{28}$ We chose to assume full reversibility in the base case for MI as well as stroke. Firstly, salt reductions are unlikely to have side effects. Secondly, salt reductions are likely to slow age related blood pressure increases, not only reduce blood pressure in the hypertensive subjects.

Because most people in Norway have systolic blood pressure above $120 \mathrm{~mm} \mathrm{Hg}$ we assumed that the total population would benefit when the whole blood pressure distribution was moved towards lower values. Analyses for the US population also demonstrated $^{29}$ that "a small reduction of 2 $\mathrm{mm} \mathrm{Hg}$ diastolic blood pressure in the mean of the populations distribution, in addition to medical treatment, could have a great public health impact on the number of $\mathrm{CHD}$ and stroke events prevented".

We based our calculations of the incidence of MI and stroke on mortality data. In our model, the annual number of strokes is currently about 20 000. This is in line with incidence data from Nord-Trøndelag and Sweden. ${ }^{16}$ Therefore, our estimation seems to yield valid results. One way sensitivity analyses even showed net cost savings when we chose the lowest alternatives for the ratios between non-fatal and fatal events.

There is evidence that reduced intake of salt will decrease the risk of gastric cancer, but this is not incorporated in the model..$^{30-32}$

The use of taxes and subsidies will induce people to eat less salt than they normally would prefer, and this "quality of life" loss is accounted for by the economic welfare loss. The estimated loss of $\$ 14$ million per year is however uncertain because detailed data on the consumption of salty food are lacking and because we do not know exactly how much the consumption is reduced by the market interventions. However, to what extent there is a permanent welfare loss is unknown because people tend to prefer less salty food when they have been on a low salt diet for some time. ${ }^{2}$ The salt intake has gone dramatically down compared with earlier times, and is, for example, on a downward slope in Japan without great public outcry. We may have had a parallel development with regard to declines in saturated fat, which also was said to have impact on quality of life, but the trend in most Western countries is decreased intake of fatty food. 
The results of the study indicate that the cost savings from avoided treatment of $\mathrm{MI}$ and stroke are $\$ 286$ millions while the health care costs in additional life years are $\$ 222$ millions (table 6). This seems contra-intuitive in that longer lives would mean more years to consume health care. However, we only included hospital costs in additional life years. If costs of other types of health care such as primary care and nursing home are included, the total undiscounted health care costs may be higher when people live longer. ${ }^{33}$ However, because health care costs of additional life years occur in the future, the present value of health care costs may still be lower with a salt reduction programme.

There has been a dramatic change in the activity concerning the treatment of stroke patients. They are more likely to be taken into hospital and referred to active rehabilitation than before and this trend is likely to continue. This may have led to an increase in hospital costs and costs of rehabilitation, but to a decrease in the nursing home costs for stroke patients.

Because the welfare losses from taxation or subsidising might be considerable and because such instruments may be politically difficult, an incremental intervention programme may be advisable. A first step could include information campaigns, declaration of salt content and development of new food products. The cost of these measures is modest, and even if the health effects were modest, this step is likely to be cost saving. A second step would then involve taxation or subsidising with higher costs (that is, welfare losses) but also greater health benefits.

To our knowledge, economic evaluation of reduced intake of salt has not been published. However, population interventions to reduce the intake of fatty foods have been undertaken. A Norwegian study concludes that such interventions are cost saving, ${ }^{34}$ while an American one $^{35}$ conclude that the cost per life year saved is very small. Reductions in the intake of salt and of fatty food have much in common. Both types of programmes have small costs per person of the population, both have small effects on the mortality rates and both have considerable effects with respect to life years saved at the aggregate level. Therefore, one would expect that the cost effectiveness of the two types of programmes would be quite similar as indicated by our study.

Economic and epidemiological analyses of a public health problem like salt and blood pressure will inevitably be uncertain. The aim of such an analysis is not to present the "truth". Rather, the aim is to present costs and consequences of a potentially important programme as fair and complete as possible.

In conclusion, the aggregate health benefits from population interventions to reduce the intake of salt may be substantial. The cost of the interventions will be modest compared with the cost savings from lower morbidity and mortality. However, if welfare losses from taxation or subsidising, are very large, the interventions will not be cost saving.

\section{KEY POINTS}

- Salt reductions are likely to reduce blood pressure and the risk of stroke and myocardial infarction.

- Model simulations show great aggregate health benefits from population interventions to reduce the intake of salt.

- The costs of population interventions will probably be off set by cost savings from fewer stroke and heart attacks.

Funding: the work has been supported by the National Council on Nutrition and Physical Activity, Norway.

Conflicts of interest: none.

1 Elliott P, Stamler J, Nichols R, et al. Intersalt revisited: further analyses of 24 hour sodium excretion and blood pressure within and across populations. Intersalt Cooperative Research Group [see comments] [published erratum BMF 1997;315:458]. BMF 1996;312:1249-53.

2 Beckmann SL, Os I, Kjeldsen SE, et al. Effect of dietary counselling on blood pressure and arterial plasma catecholamines in primary hypertension. Am $\mathcal{F}$ Hypertens 1995;8: 704-11.

3 Cutler JA, Follmann D, Allender PS. Randomized trials of sodium reduction: an overview. Am $\mathcal{f}$ Clin Nutr 1997;65: 643-51S.

4 Staessen J, Bulpitt CJ, Fagard R, et al. Salt intake and blood pressure in the general population: a controlled intervention trial in two towns. F Hypertens 1988;6:965-73.

5 Ellison RC, Capper AL, Stephenson WP, et al. Effects on blood pressure of a decrease in sodium use in institutional food preparation: the Exeter-Andover Project. $\mathcal{F}$ Clin Epidefood preparation: the
miol 1989;42:201-8.

6 Forte JG, Miguel JM, Miguel MJ, et al. Salt and blood pressure: a community trial. $\mathcal{F}$ Hum Hypertens 1989;3:17984 .

7 Tuomilehto J, Puska P, Tanskanen A, et al. A communitybased intervention study on the feasibility and effects of the reduction of salt intake in North Karelia, Finland. Acta Cardiol 1981;36:83-104.

8 Thaler BI, Paulin JM, Phelan EL, et al. A pilot study to test the feasibility of salt restriction in a community. $N Z M e d \mathcal{F}$ 1982;95:839-42.

9 Zemel MB. Dietary pattern and hypertension: the DASH study. Dietary Approaches to Stop Hypertension. Nutr Rev 1997;55:303-5

10 National Council on Nutrition and Physical Activity. Reduction of salt intake in the Norwegian population; consequences for morbidity, mortality and economy. Report 5/1998. (In Norwegian). (Nedgang 1 saltforbruket 1 den norske befolkning; hvilke konsekvenser kan det få for sykelighet, dødelighet og samfunnsøkonomien? Rapport 5/1998). Oslo, Norway:

National Council on Nutrition and Physical Activity, 1998.
1 Weinstein MC, Stason WB. Foundations of costeffectiveness analysis for health and medical practices. $N$ effectiveness analysis for heal

12 Drummond MF, O'Brien B, Stoddart GL, et al. Methods for the economic evaluation of health care programmes. Oxford: Oxford Medical Publications, 1995

13 Sonnenberg FA, Beck JR. Markov models in medical decision making: a practical guide. Med Decis Making 1993;13:322-38.

14 Statistics Norway. Causes of Death 1994 (in Norwegian) Dødsårsaker 1994). Oslo-Kongsvinger: Statistics Norway, 1997

15 Njølstad I, Arnesen E. Preinfarction blood pressure and smoking are determinants for a fatal outcome of myocardial infarction: a prospective analysis from the Finnmark Study. Arch Intern Med 1998;158:1326-32.

16 Ellekjær H, Holmen J, Indredavik B, et al. Epidemiology of stroke in Innherred, Norway, 1994 to 1996 . Incidence and stroke in Innherred, Norway, 1994 to 1996 . Incidenc

17 Selmer R. Blood pressure and twenty-year mortality in the city of Bergen, Norway. Am $\mathcal{f}$ Epidemiol 1992;136:428-40. city of Bergen, Norway. Am f Epidemiol 1992;136:428-40.
1 Norwegian Research Council (Norges forskningsråd). Management of mild hypertension (In Norwegian) (Behandling av mild hypertensjon.). Consensus conference 1997. Report no 8. Oslo, Norway: Norwegian Research Council, 1997.

19 Stensland-Bugge E, Bønaa KH, Joakimsen O. Reproducibility of ultrasonographically determined intima-media thickness is dependent on arterial wall thickness. The Tromsø Study. Stroke 1997;28:1972-80.

20 Ministry of Health and Social Affairs. The DRG System. DRG Price list including guide to coding 1997. (In Norwegian). (DRG-Systemet. Prisliste for 1997 med kodeveiledning). Oslo, Norway: Ministry of Health and Social Affairs, 1997.

21 Zethraeus N, Molin T, Henriksson P, et al. Costs of coronary heart disease and stroke: the case of Sweden. F Intern Med 1999;246:151-9

22 Andersen L, Kristiansen IS, Falch JA, et al. Cost-effectiveness of five years administration of alendronate for the prevention of of five years administration of alendronate for the prevention of
osteoporotic fractures in Norwegian women. Discussion paper no 11/1995. Oslo, Norway: National Institute of Public Health, 1995. 
23 Statistics Norway. Statistical Year Book 1996 (In Norwegian) (Statistisk årbok 1996). Oslo-Kongsvinger: Statistics Norway, 1996 .

24 Koopmanschap MA, Rutten FFH, Ineveld BM, et al. The friction cost method for measuring indirect cost of disease. f Health Economics 1995;14:171-89.

25 Ministry of Finance. Cost-benefit analysis. Principles for economic evaluation in the public sector. (In Norwegian). ( Nytte-kostnadsanalyser. Prinsipper for lønnsomhetsvurderinger i offentlig sektor). Norwegian Public Enquiries 1997: 27 (NOU 1997:27). Oslo, Norway : Ministry of Finance, 1997.

26 Hoogen van den PCW, Feskens EJM, Nagelkerke NID, et al. The relation between blood pressure and mortality due to coronary heart disease among men in different parts of the world. N Engl f Med 2000;342:1-8.

27 Stamler J, Stamler R, Neaton JD. Blood pressure, systolic and diastolic, and cardiovascular risks. US population data. Arch Intern Med 1993;153:598-615.

28 Collins R, Peto R, MacMahon S, et al. Blood pressure, stroke, and coronary heart disease. Part 2, Short-term reductions in blood pressure: overview of randomised drug trials in their epidemiological context [see comments]. Lancet 1990;335:827-38.
29 Cook NR, Cohen J, Hebert PR, et al. Implications of small reductions in diastolic blood pressure for primary prevention. Arch Intern Med 1995;155:701-9.

30 Hill MJ. Salt and gastric cancer. Eur 7 Cancer Prev 2000;7:173-5.

31 Tatsuta $M$, Iishi $H$, Baba $M$, et al. Reduction in $\mathrm{NaCl}$-enhanced gastric carcinogenesis in rats fed a high-protein diet. Cancer Lett 1997;116:247-52.

32 Ward MH, Lopez-Carrillo L. Dietary factors and the risk of gastric cancer in Mexico City. Am f Epidemiol 1999;149: 925-2.

33 Barendregt JJ, Bonneux L, van der Maas PJ. The health care costs of smoking [see comments]. N Engl F Med 1997;337: 1052-7.

34 Kristiansen IS, Eggen AE, Thelle DS. Cost effectiveness of incremental programmes for lowering serum cholesterol concentration: is individual intervention worth while? $B M \mathcal{F}$ 1991;302:1119-22.

35 Tosteson AN, Weinstein MC, Hunink MG, et al. Cost-effectiveness of populationwide educational approaches to reduce serum cholesterol levels. Circulation 1997;95:24-30. 